\title{
Intermedial Transpositions: The Visible and the Visual in Jane Urquhart's Changing Heaven
}

\section{Anne-Sophie Letessier}

\section{(2) OpenEdition \\ 1 Journals}

Electronic version

URL: https://journals.openedition.org/ces/5144

DOI: $10.4000 /$ ces.5144

ISSN: 2534-6695

Publisher

SEPC (Société d'études des pays du Commonwealth)

\section{Printed version}

Date of publication: 1 September 2014

Number of pages: 101-109

ISSN: 2270-0633

\section{Electronic reference}

Anne-Sophie Letessier, "Intermedial Transpositions: The Visible and the Visual in Jane Urquhart's Changing Heaven", Commonwealth Essays and Studies [Online], 37.1 | 2014, Online since 14 April 2021, connection on 18 July 2021. URL: http://journals.openedition.org/ces/5144 ; DOI: https://doi.org/ $10.4000 /$ ces. 5144

\section{cc) (†) $\ominus$}

Commonwealth Essays and Studies is licensed under a Licence Creative Commons Attribution - Pas d'Utilisation Commerciale - Pas de Modification 4.0 International. 


\section{Intermedial Transpositions: The Visible and the Visual in Jane Urquhart's Changing Heaven}

This paper discusses the plasticity of the ekphrasis as an instance of intermedial crossing in Jane Urquhart's Changing Heaven (1993). In this ekphrastic novel, the Canadian novelist reflects on the performative value of images and probes the mediation of language in the contemplation of paintings. Contrasting discourses on painting will be analyzed in the light of the conceptual opposition French philosopher Didi-Huberman introduces between the visiblelegible-readable, and the visual.

Jane Urquhart's fiction stands quite apart from her contemporaries' agonistic writing-back to the European aesthetic canon. Her second novel, Changing Heaven, is a rewriting of Emily Brontë's Wuthering Heights in which references to Tintoretto, Velazquez, Goya, Brueghel are scattered throughout the text in a series of descriptive tableaux inserted into the narrative structure. The parodic stance of the novel has to be construed in relation to Linda Hutcheon's definition of the complex ethos of postmodern parody (Lanone n.p.) which coalesces emulation and critical distance. ${ }^{1}$ The novel is indeed less concerned with the negotiation of a cultural heritage than with the permanent imprint that different encounters with works of art leave on the characters' minds. For Ann, the Brontë scholar obsessed with Wuthering Heights, passion appears on a stormy night when a stroke of lightning reawakens childhood memories of visits to art galleries and metamorphoses the common maples of a suburban garden into monsters from a Goya painting (78). The detour through the pictorial facilitates the longed-for crossing into the "House of Fiction" (James 7) ${ }^{2}$ by transfiguring Arthur into "a partner in storm" (80) with whom Ann will finally be able to experience the Brontëan weather. To her despair, their affair, conducted in motel rooms, has no landscape (106). It instead inhabits the "pictorial, fantasmatic space of Tintoretto's work" (Lanone n.p.) which Arthur ceaselessly describes to Ann during their illicit rendez-vous. ${ }^{3}$ Tintoretto's paintings become "a map" (107) of the two characters' affair, which the young woman fails to read as long as she superimposes on it that of Wuthering Heights.

Indeed, though Arthur is as obsessed with Tintoretto as Ann is with Emily Brontë, weather and Arthur, he is less a "partner in storm," a Heathcliff figure, than "an interpreter" (237), as he reminds her on their last night together. Doubly so, one might argue. When describing paintings, he translates - or transposes - from the visual to the verbal,

1. Hutcheon defines post-modern parody as a "repetition with critical distance that allows ironic signaling of difference at the very heart of similarity" (26). With its numerous intertextual twists (Lanone n.p.), Changing Heaven testifies to the enduring fascination with Emily Brontë's novel.

2. Henry James' expression is given a literal interpretation in the novel with Ann's continuous adaptations of the plot line of Wuthering Heights in her doll's house games, "shrinking [its] world [...] into the territory of seven small furnished rooms. Four tiny dolls live there and magnificent dramas are born among them" (20).

3. This plot development seems to stem from an unexpected analogy between the British nineteenth-century writer and the Renaissance painter, an analogy which works at several levels. It is first suggested by onomastics: Tintoretto was nicknamed "Thunderbolt" by his contemporaries (107), which is what the word "Brontë" literally means in ancient Greek (2). Both artists use what their names refer to as metonymic signifiers. While in Emily Brontë, outbursts of passion coincide with outbursts of the elements (Letissier 71), which prompts Ann to apply the Beaufort scale to her reading of the novel, Tintoretto uses lightning both as a structural device and as a means to convey the presence of the divine. 
which entails an interpretation of the forms and colours on the surface of the painting (Vouilloux 72). As an art-historian, he studies the identification, description and interpretation of the content of the image. Significantly, in the common acceptation of the term, ekphrasis can refer both to a "literary description [and] a commentary on a visual work of art" (Webster's Dictionary). The structural metaphor of "crossing" borrowed from Wuthering Heights - the path connecting Wuthering Heights to the Grange by crossing the moor - thus takes on a new meaning as, with the ekphrasis, it is related to the trans-position of one medium to another. Whether Arthur is translating or explaining images, the emphasis is laid on the meaning of the image, a meaning which can be more easily accessed by a detour through language. In the economy of the descriptive text, the three themes identified by Philippe Hamon as naturalizing the insertion of the descriptive fragment - sight, knowledge and discourse - are combined to the point of becoming indissociable (202) since knowing how to look at a painting is the subject of the art historian's discourse.

More than any of Urquhart's other ekphrastic novels - her two Kunstlerromans: The Underpainter (1997) and The Stone Carvers (2001) - Changing Heaven asks what the image does to the viewer and how it generates discourse, and thus ponders their performative value by contrasting the art historian's wordy interpretations with his lover's silent contemplation. Arthur's translation of the visual into the verbal paradoxically testifies to the fact that text/image relations do not partake of isomorphism: there can be no term to term correspondence between the pictorial marks on the surface of the canvas and the linguistic signs used to describe them. This, in turn, calls for a re-evaluation of the workings of ekphrasis which no longer relies on factual analogy - the "attempt to imitate in words an object of the plastic arts" (Krieger 6) - but on an analogy of process. The "describee" is not invited to read the description as if $\mathrm{s} /$ he were a spectator looking at a painting. Instead, with the character of Arthur, the novel dramatizes how the viewer resorts to language as a way to come to terms with an "undeniable sensation of paradox," as he tries to "apprehend more intelligibly what the image in front of him seems to be still hiding" (Didi-Huberman, Devant l'image 9, my translation). His "interpretations" of paintings hinge on the assimilation of the image to the linguistic signifying process. The explanatory discourse of the art historian is aimed at making the painting more visible, or rather more easily readable, and pertains to "the logic of translatability of what is seen in terms of knowledge" (Zimmerman 184, my translation). In Ann's experience in contemplating paintings, on the contrary, both the object and the act of looking are never merely limited to what is visible, both in the sense of what is discernible and nameable (Didi-Huberman, Ce que nous voyons 51). As is often the case in Urquhart's novels, which seem to sketch a typology of the gaze, there is a sense of unease with regards to the hermeneutic eye $e^{4}$ which strives to control experience through rational understanding and language. The novelist draws upon the plasticity of the genre of ekphrasis to probe how the visible is folded over the readable, legible and nameable as if they were equivalent (Didi-Huberman, Devant l'image 16). Yet, she cannot

4. Art critics are often portrayed as imposing sometimes convoluted interpretations, obscuring more than explaining the characters' works of art. In The Underpainter, Austin repeatedly mocks the critics' attempt to explain his work, as, for example, the "schorlarly nonsense [...] about the search for and subsequent elimination of the feminine in his [own] psyche" (151). He later adds, in a tongue-in-cheek comment, "there is nothing [...] like an obscured subject to give the critics something to talk about" (183). 
be said to belong to the admirers of the silence of painting, those who find therein a meaning that eludes language. ${ }^{5}$ The incompatibility of the two media does not lead to the aporia of the impossible silence of a text generated by images. On the contrary, her novel may be read as an attempt to make this irreducible difference the starting point of the ekphrastic discourse.

The chapter which introduces Arthur as a character traces the origin of his obsession with Tintoretto and of his vocation as an art-historian to his first encounter with the work of the Renaissance painter. During a school trip to the Toronto Art Gallery, Christ washing the feet of the disciples captivates the teenage boy, desperate for a way out of the claustrophobic interiors of his father's laundry and dry-cleaning establishment, because "[one] can move around in [the] painting" (56). The title is only alluded to at the end of the very long first paragraph: "Christ looks as if he was preparing, not to wash the disciples' feet, but to scrub the floor" (56). Here the burlesque scaling-down of the biblical episode conveys a shock of recognition, as Arthur traces details of the painting back to what he is familiar with. The passage is structured as an enumeration of every-day objects which arrest the surprised gaze: "the white towel that one of the disciples has draped over his arm like a maitre d'," "the apron-like cloth that Christ has tied around his waist" (56). The pleasure derived from recognition fuels the young boy's fascination. Arthur does not seize the image so much as he is seized by it. Contemplation almost abolishes the distance between the subject and the object. Giving himself over to the fantasy of entering the pictorial space, the young boy pictures himself as one of the characters in the scene: he "pat[s] the stationary dog, exchange[s] pleasantries with Christ" (56). With its emphasis on movement, the wandering ekphrasis bespeaks the intensity of the emotional response which transforms the surface of the painting into a three-dimensional space.

The concluding paragraph, however, introduces a rupture in tone by providing a technical explanation for the sensation of space which delights Arthur, namely "the carefully measured perspective" which creates the pictorial illusion of depth (56). The young boy's experience whets his desire for understanding, which prompts him to search for an explanation for the effect the image has on him in the production conditions of Tintoretto's work. As a young art student, he tries to reproduce the experiments of the Renaissance painter by making "miniature rooms filled with tiny wax figures [...] with little windows cut into them and candles placed outside them" (62). The fantasy of being able to "move around" in the painting gives way to the careful examination of the role of light in pictorial composition. The model allows him "to examine the effect of a low sun streaming into a room, [and] study the dispersal of light." (62, my italics) Arthur fails, however, to "gain access to the power of Tintoretto" (Perkin 123): understanding how light transfigures gesture and drapery cannot entirely account for the spell the Renaissance paintings exercise on the beholder.

Despite the disastrous ending of the experiment - Arthur sets the miniature theatre on fire and burns his hands - he ceaselessly tries to decipher the "messages" (95) he reads in Tintoretto's paintings. One in particular holds his attention throughout the

5. In his reassessment of text-image relationships, Patrick Chézaud contrasts the critics, among whom Barthes, Louis Marin, and Jean-Loup Scheffer, who adopt a semiotic approach to the visual and consider the image as a text, with those who, underlining the impossibility of a perfect correspondence between text and image, argue for a measure of inexpressibility in painting (54). 
years. In Saint George and the Dragon, "the woman, the princess, has just had some earthshattering news and she is trying [...] to get out of the painting" (95). The art-historian, of his own avowal, "can't - couldn't ever — figure out" from what she is so desperately trying to flee (95). This enigma, which presents itself as a hermeneutic challenge, is in part the result of the originality of the composition since the focal point is not the eponymous Saint George but the princess in the foreground. The narrative sequence to which the composition gives rise conveys Arthur's anxiety: "she wants out, she wants to be away and at certain moments, when Arthur has looked at the painting for too long, he fears that she wants him" (61). For the young spectator struggling between the influence of his mother's Italian "sentimentality" and his father's "stiff repression" (59) the image is doubly threatening. The description of the female figure underscores unbridled emotions which are "more frightening" than the dragon (61). As a matter of fact, the "menacing, hysterical princess" comes to represent evil itself, "so driven she is by the demons that seem to live with her inside those yards and yards of pink silk" (61). On the other hand, the male figures are ambiguous and troubling. Not only is the role of the "languid" victim given to "a young, nude man," (61) but Saint George, far from being the Christian hero fighting against evil, appears as a "poor, dutiful, underrated," "small horseman," spearing "a timid, lethargic dragon" (61). ${ }^{6}$

The princess's tumultuous drapery in Saint George and the Dragon (61), the "disturbing architectural" composition of Jacob's Ladder (106) - the art historian's discourse hinges on an "aspectual logic" (Zimmerman 184) which requires both the identification and the naming of a singular aspect of the painting. Through a metonymic process, the visual marks on the surface of the canvas become signs, in the Albertian sense of the term, that is they are discreet elements of visible signification (Didi-Huberman, Devant l'image 22). The art historian's role is then to "translate" these signs into words. After seeing the paintings of the Scuola San Rocco, Ann exclaims, when meeting her lover: "it's true about the lightning [...] you described that perfectly" (221). In other words, Arthur's analogy between lightning and a certain effect of light favoured by Tintoretto ${ }^{7}$ seems to have made his paintings more visible because they have oriented the spectator's gaze and given Ann the words to express the impression they create. Language, nevertheless, sometimes fails the art historian. When asked to describe the landscape Christ in the Garden of Gethsemene, Arthur grapples with words: "Maybe it's not landscape. Maybe it's skies and weather" (105). The taxonomic logic proves unable to satisfactorily account for what the spectator perceives, as Arthur is forced to admit. And yet, the vagueness of the description resulting from the character's hesitation is in keeping with the indeterminacy of the visual marks, which "suggest" (105) more than they represent.

Arthur's hesitation is short-lived and does not cause him to question his method, which is characterized by his attention to detail. Later on in the novel, while working on a paper on the Scuola San Rocco, he decides to focus solely on "counting and describing

6. The hermeneutic logic is redoubled as Ann intuits that the paintings "might be a map of [Arthur]" (107). For her lover, "the limits of her own existence" are as much the "borders" of the rented room (98) as their conversations about Tintoretto which "concern the wings of angels, the expression of prophets, the creation of scaffolding, painstaking sixteenth-century labour" (97). Her desire to "see herself, aglow, in the light that [his] angels cast," (107) is therefore fraught with irony. By trying to step out of the frame and "have an in" with a man who desperately wants to keep her out, she becomes the "menacing, hysterical princess," the devil in pink silk in Tintoretto's painting as she will eventually realize on their last night together (237).

7. "I'm thinking about Tintoretto's use of lighting. Most of his paintings appear to be illuminated by lightning, so that, if you look again, you are afraid that they might have returned to darkness" (105). 
angels" (209). "Counting" entails fragmenting the painting into discreet units, paradoxically to better apprehend the whole. Arthur's inventory - twelve angels in The Brazen Serpent and thirteen in The Assumption of the Virgin - pertains to a positivist reading of the image: what is visible can be divided into its constituent parts and described, describing means knowing how to look, and knowing how to look means complete understanding (Didi-Huberman, Ce que nous voyons 274). Arthur only ceases working on a set of angels when he feels "he has satisfied his curiosity" (211): that is, when he feels that his study has been exhaustive. This ideal of knowledge coalesces with the ideal of an exhaustive description which relies on both summation and totalisation (Didi-Huberman, Devant l'image 274). The text itself, nevertheless, belies the notion of exhaustion. The incremental, descriptive list - the angels, the angels "urging God the Father," the angels and the "mass of wispy drapery" - is indeed structured like a chiasmus: the mentioning of "the maelstrom of angels" prompts an unfolding of the list which concludes with a reference to "the angels fighting for space inside [a] cumulous formation" (210). What is more, the description is repeated, with variations, in the concluding passage in direct discourse. What brings the art historian's discourse to an end is not, therefore, the exhaustion of its subject.

Arthur's ekphrastic discourse in this passage evinces a second set of remarks regarding his response to visual art. When working on The Brazen Serpent, he compares the angels to fellow players on a football team. The opening phrase: "Arthur [...] knows their physical characteristics" (210) does not function as an "introductory syntagm" (Hamon 172) followed by the expected description of what he sees when he is looking at the canvas. Instead, it introduces two series of analogies drawing upon the semantic field of football which conjure an image of male complicity and convey a sense of "epistemic intimacy" (Didi-Huberman, Devant l'image 274). With the shift from visual to haptic terms and the insistence on bodily contact - "hold[ing] their muscular bodies close in the heat of leaping victory" (210) - the passage seems to allude to and play on the etymology of the verb of visual perception "to behold," which, in Old English, meant "to hold in view": the act of seeing is ultimately a tactile event in which we seize what is offered to our gaze (Merleau-Ponty 177). This may explain why, in our familiar experience of it, seeing seems to result in a gain (Didi-Huberman, Devant limage 274), all the more so for the art historian, for whom seeing is inextricably linked to the accumulation of knowledge. And yet, in the enumeration, the central analogy - "as if he [...] ha[d] tumbled with them over rough earth" (210) - belies this tone of certainty insofar as it refers to both the moment when the trajectory of the player is impeded and when he is made to lose his balance.

With its juxtaposition of a lofty subject — a scene from the Old Testament ${ }^{8}$ - and an anachronistic image of the football players "shar[ing] the same locker room," (210) the passage may be taken as a paradigm for Arthur's account of Tintoretto's paintings. For all his fascination with the "wild activity" (61) which seems to fill them, there is something decidedly bathetic in his descriptions. This somewhat irreverent attitude towards high art may be related to the parodic stance of the novel. But when it comes

8. The angels "are urging their deity, encouraging him to pay attention to what is taking place below him" (210) as Moses is about to lift the brazen serpent God has instructed him to build to heal the Israelites (Numbers 21:4-9). 
to Emily Brontë, Urquhart resorts to bathos only intermittently, ${ }^{9}$ whereas she makes it a distinguishing feature of Arthur's speech. Drawing upon the mundane - a scene from a restaurant (105), a Broadway show (106) - or the downright implausible - the almost surrealist collage of the Virgin being "helicoptered into space" (210) - his descriptions display the very working of ekphrasis as a rhetorical device since the transposition from the visual to the verbal relies on analogies, namely an identity of relation. Referring to images with which she is familiar, Arthur strives to help Ann conjure up a mental picture of an absent painting. For example, he invites her to "imagine a French waiter with wings clothed in lightning" (105). The burlesque incongruity of the juxtaposition conveys the effect of the defamiliarisation produced by Tintoretto's treatment of the subject which is touched upon in the opening sentence of the description: "There is this most wonderful angel swooping down with a tray." (105) The ekphrasis thus draws upon an analogy of effect: the text, like the painting, arrests and puzzles the listener and the reader.

Nevertheless, the analogies Arthur chooses are so contrived that they appear selfconscious. There is something of a linguistic tour-de-force in the yoking together of such incongruous elements as the Virgin and helicopters, or angels and insects. The descriptive posture becomes a pose, and one is left to wonder if these analogies serve their purpose. With the recurrence of hyperbolic structures — "how wonderfully strange [the putti] look" (105) — and superlatives — "this most wonderful angel" (105) — there is a sense of discursive excess which may be read in the light of Foucault's statement about his analysis of Velasquez's Las Meninas: "It is in vain that we say what we see; what we see never resides in what we say" (9). Language seems to exhaust itself in trying to express what another medium does, as it cannot achieve the immediacy of an image before one's eyes.

And it is in vain that we attempt to show, by the use of images, metaphors, or similes, what we are saying; the space where they achieve their splendour is not that deployed by our eyes but that defined by the sequential elements of syntax. (Foucault 9)

In Arthur's reading of the paintings, such an incompatibility is only an obstacle to be overcome. His approach posits that the image needs to be translated before it can reach intelligibility. Each of his descriptions is an "exercise in tautology" (Didi-Huberman, Ce que nous voyons 19) allowing the illusory victory of language over the image because it merely states the evidence of the visible: the painting is nothing other than what it represents, be it "cloth and weather," (61) "Rockettes," (106) or "CARE packages" angels bring to the desert (211). The act of naming, however problematically, folds the image over language as though they were equivalent.

With the alternation of chapters respectively focused on Arthur and Ann, the novel sets the two characters in contrast. In that regard, the two chapters introducing the characters function as a diptych, presenting Ann as an alternative to the hermeneutic gaze epitomized by Arthur. Both, as children, are struck by the way certain painted figures stand out against the background as if they were about to step out of their frames. While the analytical gaze of the young art-historian in training relates this impression to the construction of meaning, Ann's experience testifies to the perceptive "immediacy"

9. The narrator thus portrays the teenage Ann, Ann as a teenage girl, enthralled with Wuthering Heights, staying awake all night, "her mouth ach[ing] with the combination of desire and orthodontia" (48). 
(34) of the painting which "just is rather than signifies" (Chézaud 62, my translation). Velasquez's dwarfs "leap alive from the canvas right into the territory of [her] childhood" (34). The image asserting the sensory presence of the object it represents, the painted dwarfs are perceived as any other visual object in the child's field of vision, her "territory." Formally, the use of demonstrative - "This is immediacy" - and the metaphor work upon the referential material of language to create an effect similar to that of the image which does not partake of representation but of presentation since it "asserts its presence in the world at once" (Chézaud 61, my translation). When Ann's mother catches up with her daughter in the Velazquez gallery and immediately identifies both the subject of the paintings and the artist - "Velazquez dwarfs" (34) - she operates the shift from presentation to representation and seems to empty the image of its particular efficiency.

The opposition between the gaze of the child and the discourse of the adult echoes another passage in the novel. During her visits to the Toronto Art Gallery, Ann is drawn to portraits of children. Even though their "small sober faces" are a refuge from the "adult chaos" of the other paintings in the gallery - "Venus Bringing Arms to Aeneas, The Elevation of the Cross, Judith with the Head of Holofernes" (30) - the child is fascinated by their strange familiarity, "their bejewelled garments" (30) signaling the temporal gap which separates them from her. The little girl, once more, proves to be more intuitive than her mother, who only sees the paintings as being "cute" (31). She is indeed acutely aware that, far from cute, these children are "terrifyingly absent" (31). Giving a voice to them, ${ }^{10}$ the text expresses Ann's anxiety when faced with the scission at the core of representation. She intuits the irremediable distance between the object and its re-production on canvas which can only be a second presentation and which results in the "removal" (30) of the object (Louvel 44): the sensory presence of the painting is underlain by an irreducible absence. The portraits are akin to vanitas paintings, ${ }^{11}$ reminding the young viewer of human finitude - "Look, this is what I am ... destined to fade, destined to fly away" (31) - and, unsurprisingly, the child associates them with "the little white tombstones [...] with a carved lamb or an etched rose" she saw in country graveyards (31). Beyond its pathos, the passage reflects not only on representation but on the modality of the visual as an experience of loss when seeing means feeling that something eludes us (Didi-Huberman, Ce que nous voyons 14). The reference to tombstones crucially hinges on this notion. While the tomb asserts the visible evidence of a three-dimensional object, the act of seeing cannot reduce the image of the object to what is seen. The volume is indissociable from the void which constitutes it. Inside the tomb is a body which was similar to the viewer's but which is now drained of its life and is therefore irremediably other. The visible evidence of the tomb is thus entwined with an image that is impossible to see: what will happen to the viewer's body that will make it once again similar to the corpse inside the tomb. ${ }^{12}$ Unlike Velazquez dwarfs - and the

10. In The Sister Arts, Jean Hagstrum gives a narrow definition to the term ekphrasis. According to him it solely applies to poems in which the represented object speaks out to the reader, as in Keats's "Ode on a Grecian Urn" (18).

11. The parallel with the seventeenth-century genre of still-life painting is reinforced by the description of children "holding a bird or a flower in one raised hand" (31). Flowers, as a symbolic object of death and transience, are indeed a recurrent motif in vanitas paintings.

12. Georges Didi-Huberman sees in the tombstone an exemplary situation in which the viewer experiences the "scission of the visible." My analysis of Urquhart's text is based on the second chapter of Ce que nous voyons, ce qui nous regarde, entitled "L'évitement du vide: croyance et tautologie" (17-26). 
text explicitly opposes the two experiences (34) - the children do not leap out of their frames but seem to be receding. Ann's sensation of uncomfortably strange familiarity may thus be related to the way the image "troubles" the subject and the act of looking (Didi-Huberman, Ce que nous voyons 51, my translation).

In striking contrast with Arthur's descriptions, which partake of the visible-legible, the descriptions of Velazquez's dwarfs and of the children's portraits are minimal and stray from a mere citational effect - the titles are not given, and in the case of the portraits, the names of the artists remain unknown. Even though the reader is made to understand that the two episodes are fundamental and leave a permanent imprint on Ann's sensibility, s/he is not given the ekphrastic elaboration s/he might be expecting. There are just enough descriptive indications - the "bejewelled garments" and "sober faces" of the children (31), the "cynical" and "knowing" expressions of the dwarfs (34) - for the figures to emerge from the background. The text is structured around this lacuna, this withdrawal, which may be related with what Didi-Huberman calls "the efficiency of the visual": the "rhythmic" interplay "between surface and depth, [...] drawing and withdrawing, appearance and disappearance” (Didi-Huberman, Ce que nous voyons 13, my translation).

The same narrative strategy is sharpened in the last ekphrasis of the novel. When Arthur meets Ann on the stairs of the Scuola San Rocco, he likens two painted female saints to pictures of Emily Brontë in an effort to say something meaningful to his lover (222). The whole of the description is comprised of one sentence at the end of the chapter: "both women hold books and are seated in tempestuous landscapes," (222) the blank of the rest of the page functioning as the visible manifestation of the textual lacuna. The reader is struck by the discrepancy between the importance Arthur gives to the paintings and the silence of the text which seems to mimic the silence of the character, who, surprisingly, admits to the inexpressible nature of painting: "I never spoke to you about these, [...] I knew you would have to see them" (222). The text, however, does not remain silent. The ekphrasis works in counterpoint with the narrative development, the description the reader expects occurring two chapters later. For the first time in days, the "thick river of words" Ann has been pouring in Arthur's unwilling ears ceases when she "stands stunned, arrested in mid-sail, in front of the two paintings" (233). What she sees in them is the manifestation of self-containment.

Whatever it was [the saints] were meant to learn from experience has been taught, reflected upon, and allowed to drift away. Everything they are now, emotionally, is contained in the landscape in which they sit. The past is somewhere else, beyond the borders of the gold frame that holds them. (233)

The ekphrasis flaunts its indeterminacy at the same time as it alludes to and introduces a fundamental shift in the notion of punctum temporis used in narrative paintings, this moment in time which "can, in the picture, have all the lines of the narrative flowing into and out of it" (Krieger 88). Past and future developments in the lives of the two painted figures forever remain outside the frame of the picture and are made irrelevant in the absolute present they inhabit. The moment of captivation corresponds to a momentary muteness, a suspension of the ability of producing meaning: "Ann sees this and almost understands its possibilities" (233, my italics). She allows herself to stare at the paintings for hours without ever trying to clarify what she perceives only as a virtuality. 
Here lies the fundamental difference with Arthur's wordy ekphrasis, which ceaselessly strives to assert his certainty in what he sees. For the art historian, sight is an intellectual sense concerned with identification and objectification. By creating a character who constantly fails to "let his vision out," (60) the novel insistently seems to suggest that the visual as a modality of the gaze is flawed and that the satisfaction the spectator derives from it is an attractive lure. With Ann as the perceptual focalizer, the image ceases to be merely an object to be scrutinized - to be be-beld - but becomes an event in the course of which the spectator is momentarily seized by what she sees. She can then "let unfold, within the visible itself, the essential experience of the visual, coming towards the viewer to upset the configurations of knowledge" (Zimmerman 7, my translation).

Anne-Sophie LETESSIER

University Paul Valéry - Montpellier / EMMA

\section{Works Cited}

CHÉZAud, Patrick. "L’image Pré-texte." Texte / Image: nouveaux problèmes. Ed. Liliane Louvel and Henri Scepi. Rennes: PU de Rennes, 2005. 53-66.

Didi-Huberman, Georges. Ce que nous voyons, ce qui nous regarde. Paris: Minuit, 1992.

—. Devant l'image: questions posées aux fins d'une histoire de l'art. Paris: Minuit, 1990.

Foucault, Michel. The Order of Things: An Archeology of the Human Sciences. Trans. Alan Sheridan. London: Routledge, 2002. Trans. of Les Mots et les choses: une archéologie des sciences humaines. Paris: Gallimard, 1966.

Hagstrum, Jean H. The Sister Arts: The Tradition of Literary Pictorialism and English Poetry from Dryden to Gray. Chicago: Chicago UP, 1987.

Hamon, Philippe. Du descriptif. Paris: Hachette, 1993.

Hutcheon, Linda. A Poetics of Postmodernism: History, Theory, Fiction. London: Routledge. 1988.

James, Henry. "Preface." Portrait of a Lady. 1881. London: Everyman, 1996.

KRIEGER, Murray. Ekphrasis: The Illusion of the Natural Sign. Baltimore: Johns Hopkins UP, 1992.

Louvel, Liliane. L'Oeil du texte. Texte et image dans la littérature de langue anglaise. Toulouse: PU du Mirail, 1998.

LaNONE, Catherine. "Ghostly Voices and Arctic Blanks: from Wuthering Heights to Jane Urquhart's Changing Heaven." Cross-Talk: Canadian and Global Imaginaries in Dialogue. <http://myuminfo. umanitoba.ca/Documents/2141/LanoneC.pdf>. Consulted 10 April 2014

Letissier, George. "Brontëology as Emotional Landscaping in Changing Heaven." Resurgence in Jane Urquhart's Oeuvre. Ed. Héliane Danizon-Ventura and Marta Dvorak. Bruxelles: Peter Lang, 2010. 63-77.

MERLEAU-PONTY, Maurice. Le Visible et l'invisible. Paris: Gallimard, 1979.

Urquhart, Jane. Changing Heaven. Boston: David R. Godine Publisher, 1993.

—. The Underpainter. London: Bloomsbury, 1997.

Vouilloux, Bernard. La Peinture dans le texte: XVIIIe-XXe siècles. Paris: CNRS langage, 2005.

Zimmerman, Laurent, ed. Penser par les images. Autour des travaux de Georges Didi-Huberman. Nantes: Éditions Cécile Defaut, 2006. 